\title{
REVIEWS AND ANNOUNCEMENTS
}

Xylorama - Trends in Wood Research/Tendenzen in der Holzforschung. L. J. Kučera (editor), 212 pp., illust., 1985. Birkhäuser, Basel, Boston, Stuttgart. Price: US $\$ 21.50 ; \mathrm{sFr} 48$; DM 56 (cloth).

This attractively produced book brings together 23 essays on various aspects of wood science, dedicated to Professor Hans Heinrich Bosshard on the occasion of his 60th birthday on 9 September of this year. As such it follows the nice tradition in Switzerland of producing 'Festschrifte' to honour senior men of learning. The present reviewer can only join in the congratulations for Dr. Bosshard who has contributed so much to all aspects of wood science and whose activities as Deputy Secretary-Treasurer were crucial to the well-being of IAWA between 1957 and 1970.

A dedication to and an impressive bibliography of Dr. Bosshard's scientific output preceeds the invited contributions. The latter are arranged alphabetically by author which precludes a discussion by common themes.

J.D. Brazier reviews the anatomical characteristics of juvenile wood and discusses the importance of its volume in plantation grown forests of fast growing species. W.E. Conradie and A. Pizzi discuss the permanence and biological effectiveness of creosotes. W.A. Côté and E.B. Hanna are the authors of a general paper on electron microscopy in wood research. M.P. Denne ponders on a holistic model of wood production within a tree and demonstrates progress as well as major hurdles still to be taken in fact finding before such a model can be of predictive value. A. Fahn summarises recent research on the development of secondary tissues in plants with anomalous growth. L.P. Futo deals with wood drying and quality and includes interesting wood anatomical data in his discussion. U.P. Gasche reports on new chemical pulping processes, including one which every experienced wood anatomist will recognise as good old Franklin's maceration method. E. Gehri reviews the potential of glued laminated timber for road bridge construction. F. Hapla and W. Knigge present interesting original data on sapwood/heartwood proportions in Douglas fir from pure and mixed stands. H. Harada and J. Sugiyama give ample evidence of their recent and noteworthy model of cellulose microfibrils in Vallonia as single crystals without further substructures. J.H. Harris gives wise advice on the application of wood quality research in exotic forestry. J.P. Hösli gives a mercury porosimetric evaluation of the impregnability of wood. The editor, L.J. Kučera together with B. Eichenberger and A. Stoll, contributed the most elegant paper to this volume on the origin of lightning gaps in forests. The complexities of this old problem are lucidly explained and wood anatomical evidence is presented of collapse of developing $x y$ lem cells in apparently healthy trees struck by lightning. A. Osuský and M. Bariska report on changes in chemical composition of beech after decomposition by Trametes. H. Polge discusses the value of densitometric analysis to wood science and concludes that it has great potential for selective breeding and monitoring environmental influences. R. Popper reviews the wood/sorbate system from a submicroscopical point of view. J. Sell is the author of a paper on the uses of timber in Switzerland for exterior use. M. Sieber compares the wood anatomy of various types of roots with that of stems in a rainforest and a savanna species of Khaya from Ghana. J. Stahel analyses increment growth and forest revenues of fir stands in Klosters. B. Thunell reports on moisture conditions in PEG-treated wood of archeological ship-wrecks and recommends a museum climate for preserving the latter in dimensionally stable conditions. G. Tsoumis provides a key for the identification of sawdust derived from European conifers, which I would like to test before being convinced that the classical types of cross-field pits retain their diagnostic value in samples of which it is uncertain whether they come from earlywood or latewood. Finally $\mathrm{O}$. Wälchli gives an answer to the question why chemical protection of wood is necessary.

This bouquet of invited contributions is about as diverse as the active interests of the author of Holzkunde and gives a stimulating panorama of modern wood science. The limited printing space per contribution may be responsible for the fact that some authors do not go further than just reviewing their field rather superficially. On the other hand, these are often well-written chapters suitable for teaching purposes. Other papers report on original results of narrowly defined studies only and thus give the book its uniqueness value.

The price of Xylorama is exceedingly low, thanks to substantial sponsoring (the cost price would have been over US\$ 57 !). We must be grateful to the editor L.J. Kučera for bringing together these diverse and interesting contributions in a really festively looking Festschrift.

Pieter Baas 